\title{
ON ESTONIAN FOLK CULTURE: PRO ET CONTRA
}

\author{
Piret Õunapuu
}

\begin{abstract}
The year 2013 was designated the year of heritage in Estonia, with any kind of intangible and tangible heritage enjoying pride of place. Heritage was written and spoken about and revived in all kinds of ways and manners. The motto of the year was: There is no heritage without heir.

Cultural heritage is a comprehensive concept. This article focuses, above all, on indigenous cultural heritage and, more precisely, its tangible (so-called object) part. Was the Estonian peasant, 120 years back, with his gradually increasing self-confidence, proud or ashamed of his archaic household items? Rustic folk culture was highly viable at that time. In many places people still wore folk costumes - if not daily, then at least the older generation used to wear them to church. A great part of Estonians still lived as if in a museum. Actually, this reminded of the old times that people tried to put behind them, and sons were sent to school in town for a better and more civilised future.

In the context of this article, the most important agency is peasants' attitude towards tangible heritage - folk culture in the widest sense of the word. The appendix, Pro et contra, at the end of the article exemplifies this on the basis of different sources.
\end{abstract}

Keywords: creation of national identity, cultural heritage, Estonian National Museum, Estonian Students' Society, folk costumes, folk culture, Learned Estonian Society, material heritage, modernisation, nationalism, social changes

\section{HISTORICAL BACKGROUND}

By the end of the 19th century, the Russification period, several cultural spaces had evolved in the Baltic countries: indigenous, German and Russian. At the turn of the century, a social structure characteristic of modern society started to emerge in Estonia. Along with the rising entrepreneurship and purchasing farms for freeholds, western values became fixed in Estonian society. Estonians no longer wished to be raw material for modernisation, but demanded more power in making decisions about their own destiny. Western Europe regarded the Baltic States as part of Russia, which considerably differed from inner Russia and followed German cultural traditions. Nearly nothing was known about these indigenous peoples and they were regarded as uncivilised peasantry. 
The beginning of Estonian national movement had been inseparably connected with the evolution of civil publicity. The tradition of society movement dated back to as far as the 19th century. The turn of the century constituted an important turning point in history. The conflict escalated, as side by side with the rising new aspects, the old traditional ones existed, both in the way of living and thinking. One of the objectives of the then modernisation was to change people's everyday environment, and this inevitably brought along the re-estimation of the former. The traditional peasant way of life was gradually losing its rustic content; yet, the number of intellectuals who were able to value its essence grew considerably. In cultural life, significant events occurred both in the sphere of art and literature.

Yet, the educated Estonian of the period shaped a new ideology on the basis of the idealised folk culture, by means of which they could find in their past something to be proud of, and to prove to the whole world that Estonians were also a civilised people. In this spirit, the Estonian National Museum was founded in 1909.

\section{ESTONIAN NATIONAL MUSEUM}

The foundation for the museum collections was laid right after the establishment of the museum, and during the first decade nearly 20,000 artefacts were collected, about two-thirds of them in the years 1911-1913. The fact that a museum in which people mainly worked for free, for the good of their homeland, aimed at collecting material heritage by parishes from all over Estonia, and was able to involve tens and tens of people in this work, is unique in the history of the whole world. This action resulted in not only voluminous but also valuable collections of artefacts, which made their way to the museum before the devastating First World War broke out. Prior to the establishment of the Republic of Estonia (1918), the heritage collectors of the Estonian National Museum visited all the parishes in Estonia, except for those with Swedish population. The time was favourable. Plenty of old things were still available, although most of the collectors complained in their diaries that there was nothing to be found any more. The reports and diaries submitted after the collection expedition constitute a valuable source for research. In addition to general descriptions, they include stories about people's attitudes towards the collectors and thereby also estimates of their activity. 


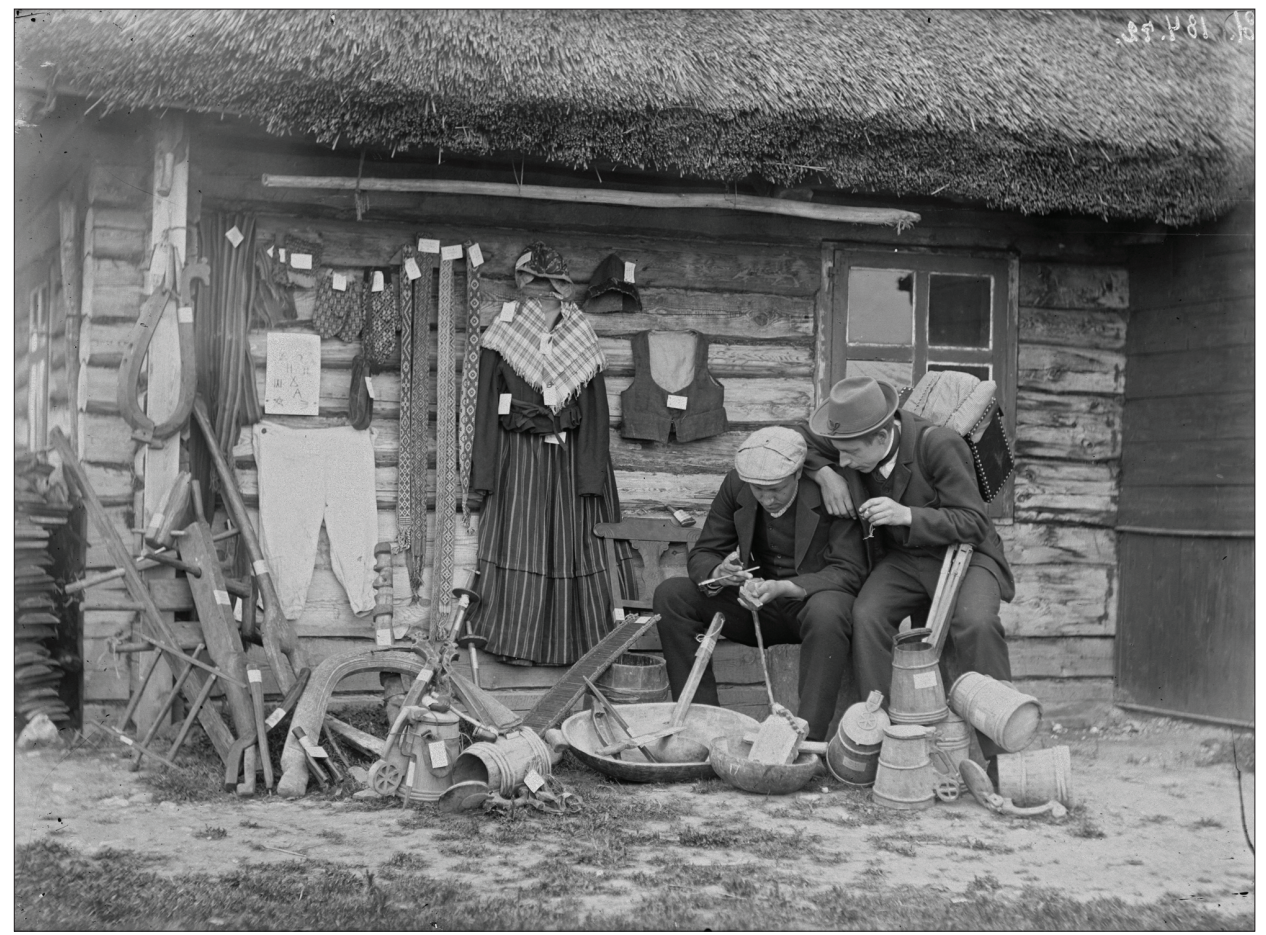

Figure 1. Heritage collectors in Karuse parish in 1912. ERM Fk 184:72.

Several cultural historians and ethnologists have made attempts to analyse Estonians' attitude towards their national heritage. Ea Jansen has dwelt upon this topic in two books $(2004,2007)$ and in an overview in the fifth volume of Estonian history (2010: 382-395). The same topic has also been analysed by Toomas Karjahärm and Väino Sirk (1997). Versatile treatments of the indigenous cultural heritage and changes in attitudes towards it have been given by ethnologists Ants Viires (2001) and Elle Vunder (2003: 47-70; 2008: 65-71); from the younger generation of ethnologists also by Anu Kannike (1994: 7-29).

In this article, I have mainly used materials from the archives of the Estonian National Museum, such as, for example, the diaries and reports of collection expeditions, as well as materials from the press of that period. 


\section{THE FIRST WAVE IN FOLK CULTURE EVALUATION IN THE LAST QUARTER OF THE 19TH CENTURY}

It was a long and hard way to the point of admitting that Estonian culture, the creation of our own people, the oral and material heritage, could be something as valuable as to be worth preserving for the future generations. For each nation, becoming aware of themselves - the birth of the nation - is one of the most significant moments in its history (Laar 2010a: 219). The activity of pastors-estophiles ${ }^{1}$ had greatly contributed to the survival and valuation of national memory. The expanding worldview in the middle of the century gave a considerable impetus to the rise of national self-awareness. The earlier social evolution had been slow, featuring only few fluctuations, yet by the third quarter of the 19th century abrupt and fast changes had occurred in Estonia. Everything important that happened in Europe reached, one way or the other, also the Baltic provinces of the Russian Empire. The spread of nationalism was especially remarkably influenced by the examples of Germany and Finland (Laar 2010b: 234).

Jakob Hurt ${ }^{2}$ had managed to make hundreds of people collect folklore; the importance of our oral folklore was well realised and the collection of folklore, thanks to Hurt's untiring work, was unprecedented. The publication of the Estonian national epic Kalevipoeg (Kalev's Son) in 1857-1861 had contributed much to the understanding of folklore as well as given an impetus to the collection work. The heyday of tangible heritage came later on. This process was typical of not only Estonia; this had also happened in other European countries earlier on.

How did the first Estonian-origin intellectuals, who came from peasant families, relate themselves to heritage? Most probably, the Estonians were enthused by the Finns, who differed by their political status, yet were similar in their folk culture.

The valuation of material culture was directly related to the idea of a museum. Several attempts were made to establish an Estonian museum; yet, the only more or less successful outcomes were the collections of the Learned Estonian Society (LES) ${ }^{3}$ and the Estonian Students' Society (ESS) ${ }^{4}$. The former, however, considered the collection of Estonian material heritage largely from the point of view of scientific interest, focusing, rather, on the preservation of the existing exotica. The few Estonian-minded voices in society were overpowered by the ruling German mentality. The reasons for kindling interest in the collection of items of Estonian folk culture came from outside the Learned Estonian Society. The 10th All-Russian Archaeology Congress was planned to be held in Riga in 1896, with accompanying ethnography exhibitions from Estonia and Latvia. As 
the LES had already participated in the former archaeology congresses, it was one of the chief organisers of the Riga congress. Preparations for the congress started already a few years earlier. In 1893, an announcement was published in the newspaper Olevik (The Present), which notified the readers about the idea of establishing a museum of old folk items, for which old artefacts were planned to be collected from people, so people were admonished to keep the objects worth preservation (Uuemad sõnumed 1893: 960). On June 19-20, 1894, the 5th Estonian Song Festival took place in Tartu. On this occasion, an exhibition was organised of all the artefacts collected until then, and it was put on display for everybody interested on two days of the Song Festival, June 19 and 20. On both days, the exhibition opened for free for a few hours. Explanations of the display were given by Oskar Kallas (Pino 1998: 40). During the two days, the exhibition drew an audience of 850 people (Kohalikud sõnumid 1894). Heritage items for the museum of the LES were collected by several members of the society. However, the LES exposition in Riga attracted no special attention in comparison to the Latvian ethnography exhibition, which had a spectacular open air section. This was the reason why heritage enthusiasm gradually faded away.

The Estonian Students' Society was rather slow to implement the idea; yet, along with the increase in nation-mindedness and following the example of Finnish students, the museum gradually started to gain ground.

The leading figure in this process was Oskar Kallas ${ }^{5}$, who collected both oral and material heritage for the LES, and also acted as a zealous agent in the establishment of the museum and the library of the Estonian Students' Society. Kallas considered it essential that artefacts were collected and preserved for the future generations; the organisation orchestrating the establishment of the museum and collecting heritage was not so important to him. His reminiscences about donating artefacts to the museum of the ESS provide the first example of pro et contra:

The primeval artefacts [of the museum of the ESS] originated from the secret treasury of my childhood, the attic of our house, which every now and then revealed some unexpected items. And my father, the sparklingeyed agent who implemented the ideas of the Society of Estonian Literati, abandoned everything without further explanations, when he heard about the scientific argumentation: Take what is worth taking! Mom had some doubts first, when I was trying to delve into the sanctuary of her clothes chest, if she was doing the right thing by unfolding her mother's keepsakes for everybody to laugh at; yet, my sister Minni, who frequently turned her warm enthusiasm in an enterprise into energetic work, ardently explained to our mother and also other sceptics that it was a great national venture and the future museum of the Estonian Students' Society, and it would 
be good to have a hand in it, enjoy pride of place in the beginning; as for later on, no one knows if there is room for anyone else. (Kallas 1923)

This is like a textbook example: the younger generation and the progressivelyminded father are able to see the value of Estonian folk culture and appreciate its significance; yet, the mother, the one to ensure continuity, cannot recognise it and is rather afraid of townspeople's disdainful attitude.

However, Kallas's society associates could not understand his admiration for material heritage. So they remarked ironically: You and your junk collection, it is as if we had won an elephant on an exhibition sale: we need to guard it, feed it, and also build a shed for it! (ibid.) As to the destiny of Estonian material heritage, the shed issue has been topical from the very beginning until today. Hopefully, this problem will eventually find a solution in the near future. ${ }^{6}$

\section{WAY TO EUROPE}

Timewise, the Estonian national movement coincided with the modernisation period. This in turn determined the necessity to define Estonians' position in the world and in the region, as well as explore and assess their relations with other peoples and cultures. With this in view, the issues of regional identity and external orientation became topical (Karjahärm 2010: 379). By the beginning of the following century, all the main trends and ideas of the western social thought had reached Estonia. The closest contacts were maintained with the northern neighbours - the Finns. Yet, we cannot underestimate the fact that already at the end of the 19th century many of our artists left for Europe via St. Petersburg, after they had studied either at St. Petersburg Academy of Arts or the so-called Stieglitz Art School' ${ }^{7}$. The most renowned figure among them was Kristjan Raud, who is also the most important one for the current topic.

The dialectics of transformation is expressed not only in the complex dialogue between the public and private social spheres, but also in the relationship between the new and the old, modernity and tradition (Vunder 2003: 47). As compared to the Awakening Period, attitude towards folk culture had changed by the first decade of the 20th century. Modernisation was targeted, above all, at changing the living environment, and this inevitably brought along the fading of traditions associated with the old way of life. Traditional peasant culture was gradually vanishing, and novel and modern phenomena were gaining ground in different spheres of life. People no more wore folk costumes or ate porridge from wooden bowls. 
As a result of the 1905 revolution, primary and secondary education became available in Estonian, and in 1906 the Emperor enforced a decree of the State Council, which stipulated that ethnic minorities were allowed to establish private schools with tuition in their mother tongue (ibid.: 383).

A number of significant events took place in cultural life: Ants Laikmaa Studio School was established in Tallinn and Kristjan Raud Studio in Tartu, the first Estonian art exhibition was organised, the Estonian Literary Society was founded in 1907, and so on. The number of periodicals increased quickly. By that time, a temporal distance had evolved, which helped to put a value on old things. The era shifted to the fore an inevitable necessity to get engaged in national culture. The most ardent advocates of national heritage were artists, with Kristjan Raud and Ants Laikmaa as the most influential among them. Raud, who had moved to Tartu in 1904, became a fervid participant in all the undertakings related to folk culture, and was specifically known as the author of articles that celebrated folk art and handicraft. At that time, the press served as a major influencing factor in shaping the public opinion. Yet, to a certain extent, Kristjan Raud's speeches and activity helped to overcome indifference.

Unlike artists, Estonian writers were not so unanimously enchanted by the folk art of the past. Despite Gustav Suits's ${ }^{8}$ famous appeal - "Let us be Estonians, but let us also become Europeans!" - the past for the members of Young Estonia, a neo-romantic literary group, was a harassing rather than encouraging factor. Yet, the older and more conservative part of writers were not following this ardency so wholeheartedly.

\section{KEEPING FOLK CULTURE ALIVE}

In the current context, research into the museum's collection work enables us to analyse, most directly and closely, people's attitude towards material folk heritage. The main initiator of the collection work was artist Kristjan Raud, who had already formerly gained experience in this sphere, as at the beginning of the century he had collected heritage items in the countryside for the museum of the LES. His attitude towards folk culture was national-romantically positive. Both Kristjan Raud's and Ants Laikmaa's texts were emotional appeals and helped to see what many contemporaries regarded as worthless junk and trash as something equal to professional art. Their writing helped to understand why creative people, who had studied abroad, turned so much attention to the old artefacts of Estonians who craved for innovations and better life (Summatavet 2007: 17). Raud repeatedly emphasised that the main aim in his life was to 
create an opportunity for painting a comprehensive picture of the life of our nation in the past (Matto).

In the early summer of 1909, the establishing year of the museum, the newspaper Postimees (The Courier) published a longer programmatic article by Kristjan Raud (1909) on the importance of collecting material heritage, in which he says:

The Estonian National Museum starts operating. The museum has in store extensive work of utmost significance, on which the future of Estonia depends in several ways. [---] This former authentic Estonian lifestyle, which was thriving in the old world, will give birth to a new life, igniting new fires, for the benefit and happiness of the future generations.

This comprehensive picture of the life of the nation in the past was very romantic. By his nature, Kristjan Raud was self-absorbed, serenely deliberate and often taciturn to the point of helplessness rather than talkative or outgoing (Kangro-Pool 1961: 69). He himself was inspired and spurred by the belief that the museum was worth establishing, and that a personal example was always the best booster in any undertaking.

This article is an attempt to provide an overview of how heritage collectors saw Estonia prior to the First World War. The efficiency of collection work and the ethnographic value of the collected artefacts, which until today have been in the focus of attention, have been left aside. By virtue of the fact that Oskar Kallas insisted on keeping a diary, we can guess what the Estonian village was like and what was Estonians' attitude towards material heritage and its collectors.

First, I would like to describe the people who followed the ENM's appeal to save what could still be saved. An average heritage collector was a young man, usually a university student, an intellectual or rather a person striving to become one. Many of the collectors were art students or artists. In 1912, the museum also decided to ask Estonian art students studying in Riga and St. Petersburg to participate in the collection work. Many of the collectors later on became renowned cultural figures - writers, artists, politicians, etc. The percentage of women among the collectors was relatively small, as at that time it was not considered acceptable for women to wander around in the countryside and ask for old artefacts on farmsteads.

In reality, heritage collection expeditions became novel and exciting ventures for many youngsters keen on arts and culture, at the same time serving as encounters with something old from somewhere in the past.

What was the vision that the heritage collectors developed about their beloved homeland during this complex work? The initial enthusiasm often crashed 


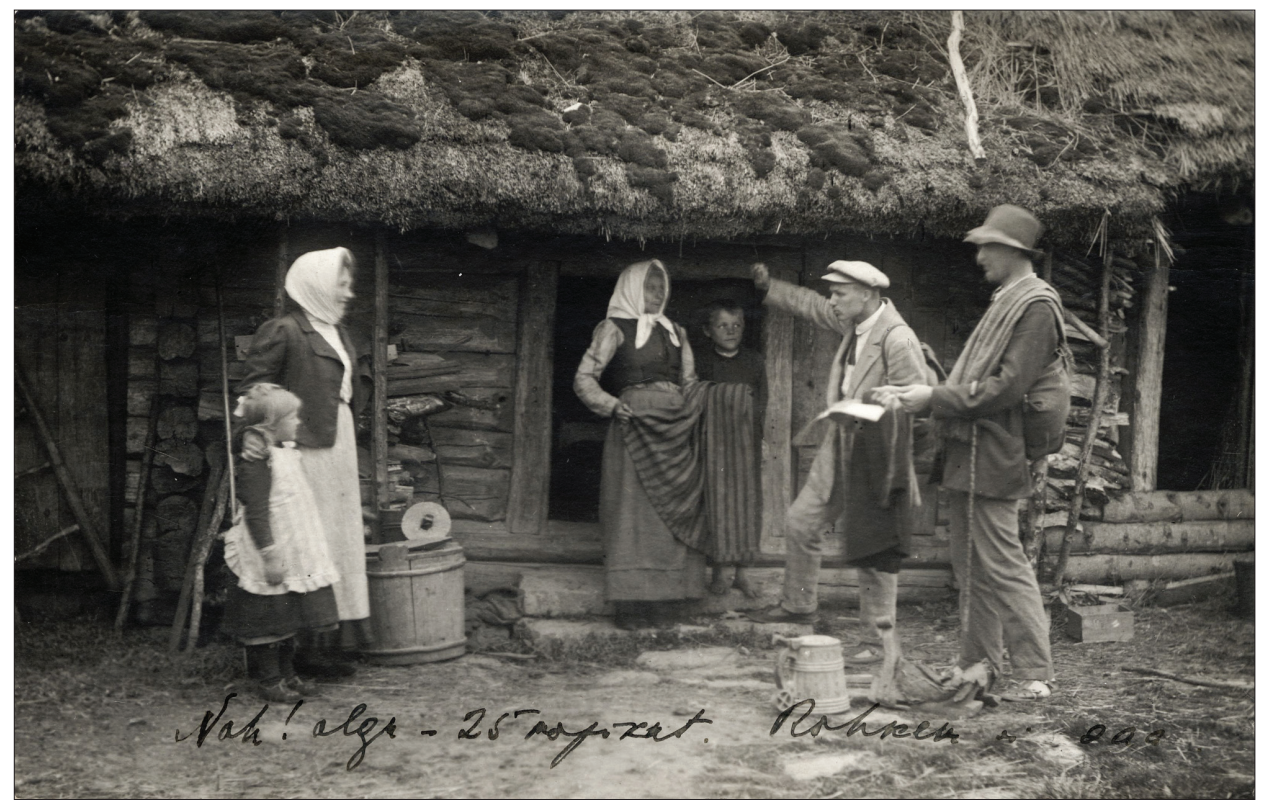

Figure 2. Heritage collectors Paul Ruus and Hans Karro in Saaremaa in 1913. ERM Fk 212:3.

against the wall of misunderstanding and the years spent at school had caused an inevitable breach. More often than not, young people analysed the things that they saw from a bystander's position. In reality the emotional slogan "I and my homeland and people are all one" did not apply any more. A certain impetus to this was also given by the museum, as they had recommended the collectors to describe both people, their appearances, characters and abodes. The expected ethnological description made the collectors assume the position of a distant viewer. For many heritage collectors, cleanliness and hygiene in farmhouses was one of the estranging factors. Although the youngsters predominantly came from the countryside, they had acquired a different kind of attitude along with education. Many diaries and reports mention these problems, if not disparagingly and directly, then at least fleetingly.

From the point of view of country people, heritage collection seemed to be an incomprehensible activity and the collectors themselves were regarded as suspicious. Local intellectuals - pastors, schoolteachers, etc. - often offered support to the heritage collectors. In case on Sunday morning the pastor had admonished people from his pulpit to welcome heritage collectors and find some old things for them, the result was always positive. 
Further on I present a few examples from heritage collectors' notes about what kind of attitude they encountered in the countryside, among the people who still mainly lived in the midst of this old folk culture, being so-called heirs of folk culture within this particular time period. I have omitted attitudes towards the museum as well as heritage collectors, and focused directly on only opinions about material heritage. The appendix presents different attitudes on the basis on diaries and reports preserved in museum archives. This can provisionally be called the lower stage of pro et contra: pro in case the attitude is rather respectful and contra in case it is disdainful.

\section{BECOMING A EUROPEAN}

Estonian culture turned from romanticism and realism to modernism in 1905, when a group of young men initiated the Young Estonia movement (19051915). Their first album of literary selections opened with the manifesto "The Strivings of Young People" by Gustav Suits, a poet and leader of the group, which proclaimed: Let us be Estonians, but also become Europeans! (Suits 1905: 3-19) This became the most influential slogan in the cultural reform for the whole century. Today, more than a hundred years later, Toomas Kiho expresses his concerns in an article under an ironic heading: Let us become Europeans, but not remain Estonians (Kiho 2013: 387-400). This indicates that more than a century we have tried to associate our culture and history with Europe.

In the second decade of the past century, European cultural life was really hectic, featuring enormous, fundamental upheavals. In Estonia, the end of the First World War and establishment of independent statehood opened the doors and also caused a certain wave of vertigo. It was a time for drinking in new ideas.

In addition to avant-gardism, Futurism, Expressionism, and Cubism were introduced from Europe but also Russia. It was highly essential to be, besides being educated, also special, modern, courageous, self-indulgent and arrogant; only then were you a truly cultured writer, poet, artist, etc. A novel behavioural type emerged - bohemianism.

A gap evolved between the more conservative, self-preservational national wing and the modern energetic younger intellectuals due to their different attitude towards national heritage. The latter maintained that for an independent country it was more important to partake in European culture than to collect innumerable tankards for the museum and advocate folk costumes.

So, for example, an interesting discussion was held in the media after the opening of the Estonian National Museum on Raadi Manor, between the Finnish-origin director of the museum, Ilmari Manninen, and Rasmus Kangro- 
$\mathrm{Pool}^{9}$, who resided in Hamburg. Despite the fact that Kangro-Pool himself had been collecting heritage items for the museum in Viru-Nigula parish ten years prior to that, he was most critical and ironic about the reviving of the old folk costume tradition. So he wrote:

The folk costume in Estonia and also in other places where it has survived is an indication of a darker, more remote corner, of how this, in its way of living, acts from force of habit of a small tribe. They have not reached the stage of evolution yet, in which the European culture and civilisation flourish that we are currently most eagerly striving for.

Estonians are not sages in sacred groves anymore; they do not singsong or participate in dances around a village swing. Only conservatism can suggest and is happy to see people in their old appearances. Because as it happens that the spirit of the time gives people their appearance (just like style to art), you could certainly also imagine a reverse process: the old appearance brings forward the way of thinking that once gave birth to this appearance. (Kangro-Pool 1923a; 1923b)

As the dream of independence had come true and the following one was to become a sterling European, this outfit was not suitable any more.

These accusations were refuted by Ilmari Manninen, director of the Estonian National Museum, in a long analysing article about the role of folk costumes, their importance and possibilities for wearing them, in which he said: It is not sensible to exchange Estonian idiosyncrasy for Europeanness (Manninen 1923). He also maintained that folk costumes could be delicately modernised, which has not always been approved by other folk costume researchers. Yet, Manninen also mentioned that not everyone was eligible to wear a folk costume:

Who are eligible to wear a folk costume? Only for the arguers' sake we have to say that Estonian folk costume is not suitable for men to wear. Men are not allowed to be as free in their clothing as women. This is one of the reasons why men often have to be ashamed of the folk costume. Besides, Estonian men's folk costumes lack any attraction. Nor do all women look good in folk costumes. Old women should beware of it. An old woman in a folk costume seems coquettish. But what about young women? Should I mention that not all of them are eligible to wear it either? Unfortunately, we can also encounter such young women who lack in-born judgemental taste and who present themselves in folk costumes for their own harm only. However, these women could also fail in choosing articles of European clothing. (ibid.) 
As we can assume from the above, Manninen limited the wear of folk costumes to only beautiful, young and refined women.

Today, however, folk dancers and singers, men and women, young and old all over Estonia wear folk costumes. No-one is worried whether the folk costume becomes them or not. The 20 th century has brought along many political upheavals and sufferings to Estonians. In hard times, people have relied on the intrinsic and homely, both on a personal and national scale. It is particularly in revolutionary times that people have turned to old traditional culture for support, overcrowding the Estonian National Museum to find examples in their ancestors' garments for making clothes for wedding, school graduation, and other ceremonies. The folk costume has become a modern Estonian's festive garment, which is good enough to go even to a presidential reception. We are not ashamed of our ancestors' sense of beauty but rather rejoice over it.

Never before in history have so many young Estonians left Estonia for Europe and even beyond. They go on both material and intellectual quests. They become Europeans and - I would really hope so - also remain Estonians.

\section{APPENDIX}

\section{Examples of pro et contra}

The below examples are presented in proportion with the entire material. Founded on this, we can presume that common people had not fully recognised the value of their old household commodities and folk costumes as cultural heritage. Arrogant and disdainful attitude towards old artefacts could be encountered considerably more frequently and sometimes the collectors themselves fell under the influence. The aim of the activity was incomprehensible to people and it often remained so also after detailed explanations.

\section{Pro}

But it was namely these old men and women who still wear folk costumes, who refused to give me a stitch of their clothing, either by donating or by selling. The master of Lauri farmstead only promised that, when he died, his folk costumes would be donated to the Estonian National Museum. (TAp 66, w/o number) 


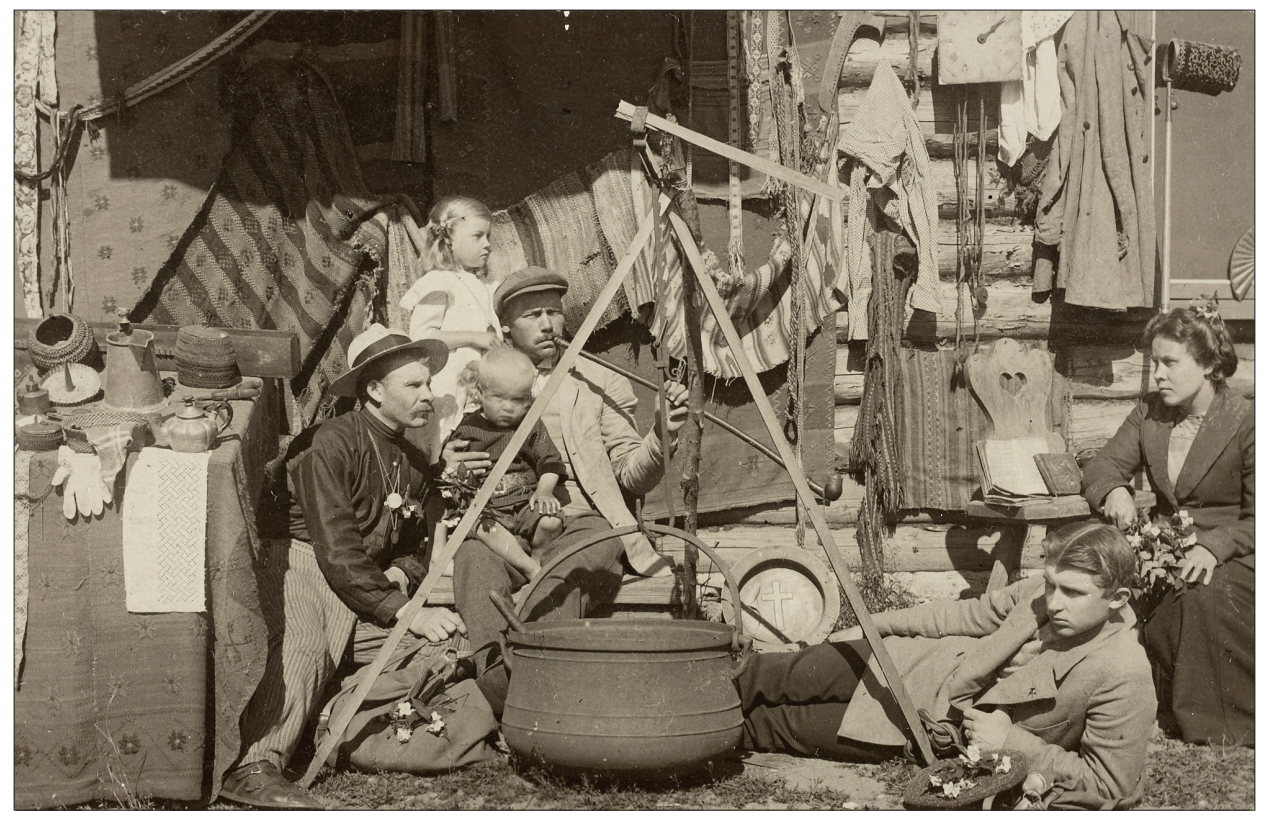

Figure 3. Heritage collectors with obtained artefacts in Kadrina in 1914. ERM Fk 362:70.

At Tahkuranna, people willingly showed us their old garments, explaining that this skirt had been woven by the granny herself and that coif, God knows from which generation, was godmother's present, etc. However, they were all carefully put back into the chest again. And when we wanted to have them for the museum, they started [---] to plead with us. "Dearies, please don't ask, you cannot buy memories for money; Mother wouldn't ask me to come to her funeral this way...”, etc. (TAp 15: 5)

In the whole parish, only three people cherished their old family relics so much that they decided not to part with them. (TAp 5: 44)

As soon as we had explained to a farmer's wife that we wanted the things for a kind of permanent display, for a museum, we heard: "How could I discard my mother's relics; let them better be in the chest, at least I can sometimes have a look at them myself," and the chest lid was slammed shut, so that we had nothing else to do but bid a sad farewell to these things. (TAp 94: 1) 
In the whole parish, I found only one family, whose hundred-year-old garments looked quite new; for example, a man's jacket, which I was barely able to get hold of. However, they wouldn't give me the so-called iron vest ${ }^{10}$ and the shortcoat. The man was even ready to let go of it, but the woman wouldn't. She said that she was an Estonian and she also wanted her children to be Estonians. The iron vest and the shortcoat were supposedly the best means to achieve it. In Tartu they may survive, maybe even forever, but Hiiumaa is far away and a trip to Tartu is expensive, so that one cannot count on being able to show these things to one's children there. I suggested she could sell the old things to the museum and for this money make new ones. However, she didn't think it was possible either. She said it was just like giving a hungry person a stone instead of bread. I didn't insist any more. It is really good if a person is in such a disposition that she sees her forefathers and foremothers and their souls in the garments, finds consolation, spiritual improvement and companions in bad luck in them, and would not give away these precious things of spiritual value for money. I made her promise that, when her children obviously seemed to be Estonians already, she would bequeath her garments to the Estonian National Museum in her will. (TAp 39: 2-4)

An expensive thing in Hiiumaa is the seppel (chaplet), a bride's headdress. If you happen to have it, you can get one rouble if you lend it out to a bride. Therefore, they ask a high price for it, five to ten roubles. I encountered a woman who was not well off, or maybe just short of money at the moment. And although she sold me her foremothers' inheritance, she cried when she had to depart from it. So I felt as if I had killed the old woman's ancestors by making this purchase. (TAp 39: 4)

On one farmstead, we found a tankard decorated with various patterns, and the farmer wanted to give it to the museum; yet, his wife pulled it out of his hand and said: "Do you think you will become honest again by giving it away?” (TAp 169: 21)

\section{Contra}

Naestevälja village is in the woods and far away from the others; despite this, there are no old things there. Everything was destroyed already 20 years ago. (TAp 65, w/o number) 
An old female cottager even grabbed a cudgel when she understood what I wanted, and said: "What should ragmen do if such gents start picking rags? Beat it!” (TAp 66, w/o number)

It's a pity we couldn't make this trip to Tahkuranna ten years sooner; we would have found a lot more then. Jews ${ }^{11}$ had devastated it all, taking silver brooches, bracelets, and so on. Garments and other things that were no good for them had been collected for the Pärnu Museum. (TAp 15: 4)

After long explanations they finally believed that the museum really existed; yet, they didn't understand why such old things were collected for it. A common question was: "Why such educated gents collect these old things; you could easily buy them from rag-and-bone men?"And then we had to explain, over and over again, what the difference was between the museum and a rag-and-bone man, and so on, which by the evening exhausted both our feet and voices. (TAp 136: 5)

$\ddot{A} k s i$ must be one of the most educated parishes and, therefore, also poor in old artefacts, as our educational system did not teach people how to respect themselves, their homeland and their mother tongue. (TAp 63: 5)

In another place, an old woman called Kettu, who had an old tankard, tried to warn us: "How do such handsome gents like you dare to collect such tacky old things; you wouldn't dare to pass through the village with this, someone is going to chase you with a cudgel.” (TAp 5: 43)

An old corvée-time man (Andres Pede) had a very peculiar opinion about heritage collection: "Well, I can't understand why you are collecting these old things; do you want to bring back old times? You go to the emperor and show him how people used to live and how they are flaunting now." [We explained to the old man that this was not the case.] (TAp 5: 46)

Jewellery, especially silver brooches and the like, having gone out of fashion, had been sold to the Jews or exchanged for something else in town. (TAp 4: 1-2)

Local agricultural associations (in Vigala and Märjamaa) contributed significantly to the destruction. So, for example, couple of years ago the Vigala Agricultural Association organised an exhibition sale. Like always, collectors were sent out, and they went from one farm to another, looking 
for artefacts. Within this process, as the members of the association told us, they also happened to lay their hands on items of heritage, such as wedding tankards, women's clothing, headgear, olden tools, etc. Quite often you could hear: we used to have fancy wedding tankards, but we gave them away - for the exhibition. And nothing good happened to the things that had been given for the exhibition. (TAp 94: 7)

An old woman was seriously worried about my brains: how could a sane person waste time and spend money on collecting old trash. (TAp 110: 6)

There are also places where people look disdainfully at olden things. So a farmer's daughter (M. Eller) told us that she had burnt a 200-year-old ornamented cupboard just because young people visited their farm and this old thing was really "ugly". (TAp 5: 44)

However, sometimes we encountered opposing opinions within the same family. An aged man sells us the Bible dating from 1731. His wife vehemently objects to this, saying that it is a forefathers' keepsake, with all the ancestors' names and birthdates written down on the cover. The man, who seems to be open-minded and rational, copies the family chronicle on the cover of a calendar and trades with us for the book. (TAp 75: 6)

Translated by Tiina Mällo

\begin{abstract}
ABBREVIATIONS
ERM EAV - Ethnographic Archive of the Estonian National Museum ERM Fk - Photographic collection of the Estonian National Museum TAp - Topographic Archive diary
\end{abstract}

\title{
NOTES
}

1 Estophiles are people not of Estonian descent who are sympathetic to or interested in the Estonian language, literature and culture, history, and Estonia in general; especially Baltic-German scholars who in the late 18th to early 19th century began documenting and promoting the Estonian language and culture.

2 Jakob Hurt (1839-1907) was an Estonian folklorist and linguist, pastor and public figure. 
3 The Learned Estonian Society, founded in 1838; German: Gelehrte Estnische Gesellschaft, (GEG), closed down in 1950 and re-established in 1988, is the oldest scientific society in Estonia.

4 The Estonian Students' Society is a student organisation established in Tartu in 1870. In 1940, after the Soviet Union had occupied Estonia, all student organisations were closed down. The ESS continued its activity as an underground organisation. Beginning in 1945, the ESS operated openly in exile (Sweden, Germany, Australia, Great Britain, Canada, the USA and Argentine). In 1988, the Estonian Students' Society was re-established in Tartu.

5 Oskar Philipp Kallas (1868-1946) was Estonian folklorist and diplomat.

6 The construction of a special museum building for the Estonian National Museum started in spring 2013.

7 With an official name: Stieglitz St. Petersburg State Academy of Art and Industry.

8 Gustav Suits (1883-1956) was an Estonian poet and literary critic.

9 Rasmus Kangro-Pool (December 20, 1890 - May 9, 1963) was an Estonian literary, art and theatre critic.

${ }^{10}$ A thick felted (probably grey) woollen vest.

${ }^{11}$ Peddlers of Jewish origin travelled the country, trying to buy up old artefacts, and especially silver jewellery, at a bargain price.

\section{ARCHIVAL SOURCES}

\section{Topographic archive of the Estonian National Museum}

TAp 4 = Gustav Wilbergi aruanne Eesti Rahva Muuseumi heaks asjade korjamise üle Kolga randades Kuusalu kihelkonnas 1910.a. suvel. [Gustav Wilberg's report on collecting artefacts for the Estonian National Museum on the coast of Juminda Peninsula, Kuusalu parish, in the summer of 1910.] Report dated 18.09.1910, $10 \mathrm{pp}$.

TAp 5 = Üliõpilaste J. Kompuse ja O. Kuriksi aruanne ainelise vanavara korjamise kohta Rannu kihelkonnas 1910 aastal. [Report on the collection of material heritage by students J. Kompus and O. Kuriks in Rannu parish in 1910.] 50 pp.

TAp 15 = Vanavarakorjaja Voldemar Lindpere reisikirjeldus 1911. a. [Heritage collector Voldemar Lindpere's travel report from 1911.] $5 \mathrm{pp}$.

TAp 39 = E. Michelsoni ainelise vanavara korjamise aruanne ( $\mathrm{k} / \mathrm{r} 61$ juurde) 1912.a.

[E. Michelson's report on the collection of material heritage from 1912.] $9 \mathrm{pp}$. 
TAp 63 = Marie Heibergi aruanne vanavara korjamise üle Äksi kihelkonnas 1912. a. mais. ERMi k/r 68 juurde. [Marie Heiberg's report on the collection of material heritage in Äksi parish in May 1912.] 5 pp.

TAp 65 = Korjaja Georg Grossi päevaraamat (diar 11). 8.06.-25.06.1913. a. Ambla kihelkond. [Collector Georg Gross's diary. Ambla parish, June 8-25, 1913.] 30 pp.

TAp 66 = Vanavarakorjaja A. Kasekampi mõned täiendavad märkused vanavara korjamise kohta. Alustatud 21. aprillil 1913. [Heritage collector A. Kasekamp's supplementary remarks on heritage collection. Started on April 21, 1913.] 5 pp.

TAp 75 = Albert Saabergi päevaraamat vanavara korjamisel 11.05.-22.05 1913. a. Jüri kihelkond. [Albert Saaberg's diary at heritage collection on May 11-22, 1913; Jüri parish.] 7 pp.

TAp 94 = Korjajate A. Reiniku ja J. Grünbergi vanavara korjamise aruanne Märjamaa kihelkonnas. 1. juuni-15. juuli 1913. a. [Report on the collection of material heritage by A. Reinik and J. Grünberg in Märjamaa parish. June 1 - July 15, 1913.] $11 \mathrm{pp}$.

TAp 110 = Eesti Rahva Museumi asjade korjaja A. Kruusbergi lühike reisikirjeldus. (Suvel 1913.) [Short travel report by A. Kruusberg, collector of the Estonian National Museum. (Summer of 1913.)] 8 pp.

TAp 136 = J. Tenteri ja A. Lehe vanavarakorjamise aruanne 1914.a. Juuru kihelkond. [Heritage collection report by J. Tenter and A Leht, Juuru parish, 1914.] 23 pp.

TAp 169 = Ed. Depmani vanavara korjamise aruanne Viljandimaal ERM k/r 309 juurde. 1914 ja 1915. a. Viljandi ja Paistu kihelkond. [Ed. Depman's heritage collection report in Viljandimaa to collection register 309. 1914 and 1915, Viljandi and Paistu parishes.] 29 pp.

\section{Ethnographic Archive of the Estonian National Museum: Miscellaneous}

Matto = Gustav Matto. Kristjan Raud - eesti vanavara kogumise suurmehi. Tema 100-ks sünnipäevaks. [Kristjan Raud: Grand old man of Estonian heritage collection. 100th birth anniversary.] ERM EAV 16:2.

\section{REFERENCES}

Jansen, Ea 2004. Vaateid eesti rahvusluse sünniaegadesse. [Insights into the Birth Period of Ethnic Estonian Nationalism.] Tartu: Ilmamaa.

Jansen, Ea 2007. Eestlane muutuvas ajas: seisusühiskonnast kodanikuühiskonda. [Estonians in a Changing World: From Estate Society to Civil Society.] Tartu: Eesti Ajalooarhiiv. 
Jansen, Ea 2010. Kultuuriline murrang. [Cultural Upheaval.] In: S. Vahtre \& T. Karjahärm \& T. Rosenberg (eds.) Eesti ajalugu V. Pärisorjuse kaotamisest Vabadussõjani. Tartu: Ilmamaa, pp. 382-395.

Kallas, Oskar 1923. Eesti rahva muuseumi algaegadelt 2. [From the Initial Years of the Estonian National Museum.] Newspaper Postimees, No. 158, June 17, p. 4. Available at http://dea.nlib.ee/fullview.php?pid=s208963\&nid=46795\&frames et=1, last accessed on June 3, 2014.

Kangro-Pool, Rasmus 1923a. Rahvariie. [Folk Costume.] Newspaper Päevaleht, No. 224, August 25, p. 8. Available at http://dea.nlib.ee/fullview.php?pid=s402534\&nid=2 67509\&frameset=1, last accessed on June 3, 2014.

Kangro-Pool, Rasmus 1923b. Rahvariie. [Folk Costume.] Newspaper Päevaleht, No. 225, August 26, p. 4. Available at http://dea.nlib.ee/fullview.php?pid=s402535\&nid=2 67510\&frameset=1, last accessed on June 3, 2014.

Kangro-Pool, Rasmus 1961. Kristjan Raud ja Eesti Rahva Muuseum. [Kristjan Raud and the Estonian National Museum.] In: R. Kangro-Pool (ed.) Kristjan Raud 1865-1943. Tallinn: Eesti NSV Kunst, pp. 66-84.

Kannike, Anu 1994. "Rahvuslik" rahvakultuur / "National" Folk Culture. Pro Ethnologia, Vol. 2. Tartu: Eesti Rahva Muuseum, pp. 7-29. Available at http://www.erm.ee/ pdf/PE2.pdf, last accessed on June 3, 2014.

Karjahärm, Toomas 2010. Eestlus ja eurooplus. [Estonianness and Europeanness.] In: S. Vahtre \& T. Karjahärm \& T. Rosenberg (eds.) Eesti ajalugu V. Pärisorjuse kaotamisest Vabadussõjani. Tartu: Ilmamaa, pp. 379-380.

Karjahärm, Toomas \& Sirk, Väino 1997. Eesti haritlaskonna kujunemine ja ideed 1850 1917. [Formation of Estonian Intellectuals and Their Ideas in 1850-1917.] Tallinn: Eesti Entsüklopeediakirjastus.

Kiho, Toomas 2013. Saagem eurooplasteks, kuid ärgem jäägem eestlasteks. [Let's Become Europeans but not Remain Estonians.] Akadeemia, Vol. 3, pp. 387-400. Available at http://digar.nlib.ee/digar/show/?id=130698, last accessed on June 3, 2014.

Kohalikud sõnumid 1894 = Kohalikud sõnumid. [Local News.] Newspaper Postimees, No. 140, June 30, p. 3. Available at http://dea.nlib.ee/fullview.php?pid=s333184 \&nid=3186\&frameset=1, last accessed on June 3, 2014.

Laar, Mart 2010a. Rahvuslus ja eelärkamisaeg. [Nationalism and Pre-Awakening Period.] In: S. Vahtre \& T. Karjahärm \& T. Rosenberg (eds.) Eesti ajalugu V. Pärisorjuse kaotamisest Vabadussõjani. Tartu: Ilmamaa, pp. 219-233.

Laar, Mart 2010b. Ärkamisaja algus. [Beginning of the Awakening Period.] In: S. Vahtre \& T. Karjahärm \& T. Rosenberg (eds.) Eesti ajalugu V. Pärisorjuse kaotamisest Vabadussõjani. Tartu: Ilmamaa, pp. 234-245.

Manninen, Ilmari 1923. Rahvariietest: Pro et Contra. [About Folk Costumes: Pro et Contra.] Newspaper Päevaleht, No. 238, September 8, p. 8. Available at http:// dea.nlib.ee/fullview.php?pid=s402550\&nid=267526\&frameset=1, last accessed on June 3, 2014.

Pino, Veera 1998. O. Kallase noorusaeg ja õpingud. [Youth and Studies of O. Kallas.] In: K. Aru (comp.) \& S. Olesk (ed.) Oskar Kallas. Artikleid Oskar Kallase elust ja tööst. [Oskar Kallas: Articles about Oskar Kallas's Life and Work.] Tartu: Eesti Kirjandusmuuseum, pp. 13-66. 
Raud, Kristjan 1909. Eesti Rahva Museum. Ainelise vanavara korjamisest. [About Collecting Material Heritage.] Newspaper Postimees, No. 126, June 10, p. 1. Available at http://dea.nlib.ee/fullview.php?pid=s232539\&nid=5911\&frameset=1, last accessed on June 3, 2014.

Suits, Gustav 1905. Noorte püüded. Üksikud mõtted meie oleviku kohta. [Strivings of the Youth.] Noor-Eesti I. Tartu: Kirjanduse Sõprade Kirjastus, pp. 3-19.

Summatavet, Kärt 2007. Mõningaid mõtteid kunstist, Kristjan Rauast ja vanavara kogumisest. [Reflections on Art, Kristjan Raud and Collecting Tangible Heritage.] Mäetagused, Vol. 37, pp. 7-44. doi:10.7592/MT2007.37.summatavet.

Uuemad sõnumed 1893 = Uuemad sõnumed. [Recent News.] Newspaper Olevik, No. 45, November 8, pp. 960-961. Available at http://dea.nlib.ee/fullview.php?pid=s375 $338 \&$ nid=112407\&frameset=1, last accessed on June 3, 2014.

Viires, Ants 2001. Kultuur ja traditsioon. [Culture and Tradition.] Tartu: Ilmamaa.

Vunder, Elle 2003. Moderniseerumine ja kultuurimustrite muutused Eestis 19.-20. sajandil. [Modernisation and Changes in Cultural Patterns in Estonia in the 19th-20th Centuries.] Eesti Rahva Muuseumi aastaraamat XLVII. Tartu: Eesti Rahva Muuseum, pp. 47-70.

Vunder, Elle 2008. Agraarühiskond ja rahvakultuur. [Agrarian Society and Folk Culture.] In: A. Viires \& E. Vunder (comps.) Eesti Rahvakultuur. Tallinn: Eesti Entsüklopeediakirjastus, pp. 65-71. 